\title{
Saint Jacques et la France. Actes du Colloque des 18 et 19 janvier 2001 à la Fondation Singer-Polignac, réunis sous la direction d'Adeline Rucquoi
}

\section{G. Matteo Roccati}

\section{(2) OpenEdition}

\section{Journals}

Édition électronique

URL : http://journals.openedition.org/studifrancesi/29963

DOI : $10.4000 /$ studifrancesi.29963

ISSN : 2421-5856

Éditeur

Rosenberg \& Sellier

\section{Édition imprimée}

Date de publication : 1 avril 2006

Pagination : $129-130$

ISSN : 0039-2944

\section{Référence électronique}

G. Matteo Roccati, «Saint Jacques et la France. Actes du Colloque des 18 et 19 janvier 2001 à la Fondation Singer-Polignac, réunis sous la direction d'Adeline Rucquoi », Studi Francesi [En ligne], 148 (XLX | I) | 2006, mis en ligne le 30 novembre 2015, consulté le 24 avril 2021. URL : http://

journals.openedition.org/studifrancesi/29963; DOI : https://doi.org/10.4000/studifrancesi.29963

Ce document a été généré automatiquement le 24 avril 2021.

\section{c) $(9 \ominus$}

Studi Francesi è distribuita con Licenza Creative Commons Attribuzione - Non commerciale - Non opere derivate 4.0 Internazionale. 


\title{
Saint Jacques et la France. Actes du Colloque des 18 et 19 janvier 2001 à la Fondation Singer-Polignac, réunis sous la direction d'Adeline Rucquoi
}

\author{
G. Matteo Roccati
}

\section{RÉFÉRENCE}

Saint Jacques et la France. Actes du Colloque des 18 et 19 janvier 2001 à la Fondation SingerPolignac, réunis sous la direction d'ADELINE RUCQUOI, Paris, Les Éditions du Cerf, 2003, pp. 528.

1 Le volume rassemble une vingtaine de contributions; pour la plupart, elles sont de caractère historique et portent sur les établissements religieux liés au pèlerinage de Compostelle et au culte de saint Jacques, ainsi que sur les enseignes de pèlerin et le culte de certains saints (Léonard, Saturnin). CELLE de FRANCIS RAPP a pour objet Les humanistes et les réformateurs face au pèlerinage au XVI siècle, pp. 505-518. Un long mémoire est consacré à l'iconographie et, tout particulièrement, au «caractère novateur des 'images' écloses à la faveur de l'érection de l'Hôpital Saint-Jacques, surgi à Paris dans la décennie 1320-1330", 'images' dont l'étude mesure l'impact sur l'espace français et européen (HUMBERT JACOMET, Saint-Jacques: une image à la française? L'iconographie suscitée par la création de l'hôpital Saint-Jacques-aux-pèlerins et ses prolongements (XIV $\mathrm{e}^{\mathrm{X}} \mathrm{XV}$ s.), pp. 85-262).

2 L'aspect « littéraire » est plus spécialement pris en compte dans les articles suivants. MANUEL C. DIAZ Y Diaz examine L'épittre préliminaire du «Liber Sancti Jacobi », pp. 323-330. PIERRE-GILLES G IRAULT, Compostelle dans les chansons de geste françaises, une approche chronologique, pp. 331-348, souligne l'apparition tardive des références aux pèlerinages et notamment à celui de Compostelle (dernier tiers du XII ${ }^{e}$ s.) et remarque que « toute 
la matière qui, dans l'épopée française, associe Charlemagne et Compostelle procède exclusivement du Pseudo-Turpin » (p. 347). NICOLE BÉRIOU, Le pèlerinage de saint Jacques vu par les prédicateurs du XIII siècle, pp. 349-368, constate que peu de mentions explicites sont faites du pèlerinage de saint Jacques; en revanche le sens spirituel et pénitentiel des cheminements pèlerins, notamment en référence à l'image alors récente du Christ pèlerin, est l'objet de la réflexion des prédicateurs et l'occasion d'une "remise en ordre» de leur part. MARIE ANNE Polo DE BeAUlieu, Saint Jacques et les pèlerins dans les "exempla», pp. 369-394, étudie les sources dominicaines (Vincent de Beauvais, Jacques de Voragine) et les recueils d'exempla (Alphabetum narrationum, Scala coeli) de manière à repérer la circulation et la fortune des récits; elle dégage ensuite les caractéristiques des modèles, et contre-modèles, proposés (motivations des pèlerins, règles du pèlerinage, aides miraculeuses, etc.). Enfin MICHEL ZINK dans La coquille et les poètes français médiévaux, pp. 395-403, traite de la métaphore de l'amant pèlerin, le séducteur, et de la coquille, la tromperie. 